\section{PATENT WATCH}

\section{Opposition division goes to Edinburgh}

In a case that revolves around the question of whether it is morally justifiable to grant claims that cover genetically modified embryonic stem cells, the 'Edinburgh' patent recently survived — although not without alteration the oral proceedings of the Opposition Division of the European Patent Office (EPO). The patent, so-called because one of the co-authors works at the University of Edinburgh, describes a method of using genetic engineering to isolate stem cells from more-differentiated cells to obtain pure stem-cell cultures. The original patent covered embryonic stem cells, which triggered a major discussion of the patenting of human stem-cell technology. The opposition procedure allows the filing of appeals against granted patents. Impartial arbiters, who are appointed by the EPO — in this case three patent examiners and a legal expert - decide the fate of the opposed patent. The governments of Germany, Italy and the Netherlands, as well as Greenpeace, started the legal challenge to the original patent. The opposition division took the view that some parts of the patent did not comply with the European Patent Convention, in particular with one part that stipulates that human embryos cannot be patented for industrial and commercial purposes. An amended patent was introduced, which, although it still covers modified human and animal stell cells, excludes both embryonic stem cells and human germ-line intervention.

WEB SITE European Patent Office: http://www.european-patent-office.org/ Mountford, P. S. \& Smith, A. G. Isolation, selection and propagation of animal transgenic stem cells, EP Patent 0695351 (2000)

\section{US patent office, interfering again}

The US Patent and Trademark Office (USPTO) has said that a Genentech-University of Pennsylvania patent application relating to anti-HER2 antibodies might take priority over a related Chiron patent. According to Genentech, the USPTO has declared an interference between the two claims. The interference proceeding, conducted before the Board of Patent Appeals and Interferences, decides who was first to make a particular invention if two or more parties claim the same invention, and consequently, who is entitled to a patent on the invention. The USPTO has determined that there is a substantial question as to whether the inventors of the Chiron patent were first to invent this technology and are entitled to the patent. If the Patent Office was to decide that the inventors of the Genentech-University of Pennsylvania patent application were first, and that their claims are patentable, a new patent would be issued to them and the Chiron patent would be revoked. Coincidently, Genentech is battling Chiron at present over the same issued patent in a California Federal District Court. Chiron alleges that the sale of Genentech's Herceptin (trastuzumab) - an anti-HER2 monoclonal antibody - infringes its patent, whereas Genentech alleges that Chiron's patent is invalid.

WEB SITE US Patent and Trademark Office: http://www.uspto.gov/

Ring, D. B. Antigen-binding sites of antibody molecules specific for cancer antigens. US Patent $6,054,561$ (2000)

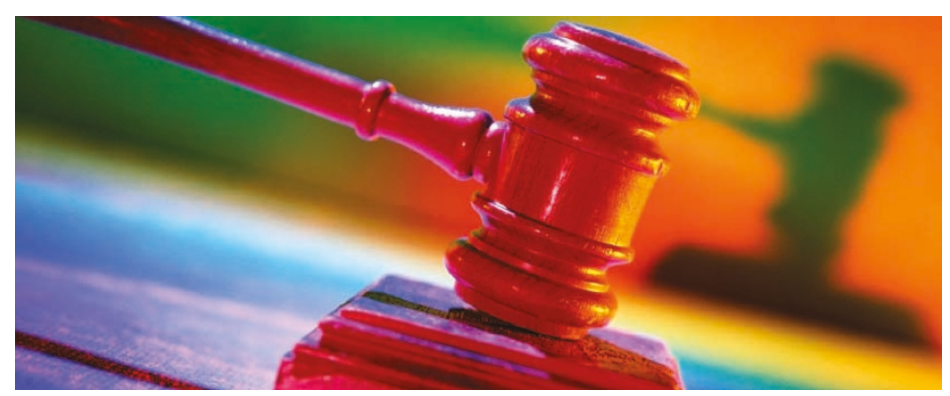

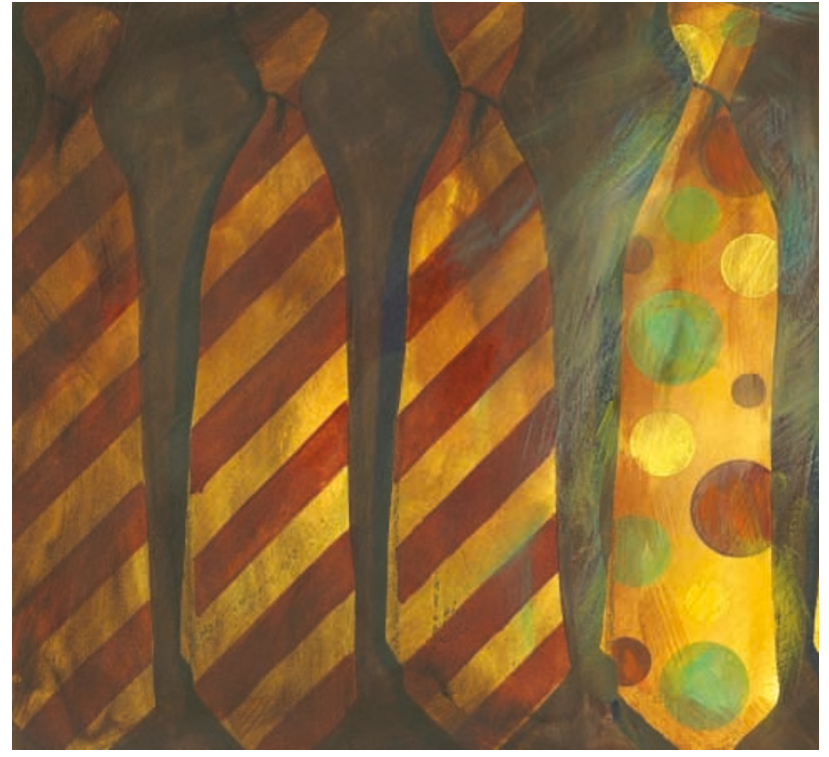

LIGANDS

\section{Sorting good from bad}

It's never easy finding clinically relevant ligands for receptors. Although you might have identified an appropriate receptor to target, you soon find out from preclinical models that as well as being involved in the pathway of interest, it is involved in other pathways that will produce unwanted side effects. But, according to a study by Lee Limbird and colleagues in Proceedings of the National Academy of Sciences, the key to sorting out the physiological wheat from the chaff might be to characterize the physiological and behavioural responses in mouse models that are heterozygous for the receptor of interest.

The authors looked at the $\alpha_{2 \mathrm{~A}}$-adrenoceptor $\left(\alpha_{2 \mathrm{~A}}-\mathrm{AR}\right)$, as genetic manipulation of this receptor in mice had shown that it was involved in several responses - both clinically desired (for example, hypotension) and unwanted (for example, sedation). So, they were surprised to find that in heterozygous models $\left(\alpha_{2 A}-A R^{+/-}\right.$mice $)$supramaximal doses of $\alpha_{2 \mathrm{~A}}$-agonists lowered blood pressure without affecting sedation, implying that more than $50 \%$ of $\alpha_{2 \mathrm{~A}}$-AR must be activated to cause sedation.

Limbird and colleagues hypothesized that differing fractional activation of receptors by using partial agonists (or alternatively by administering incremental doses of a full agonist) could produce these selective responses. This idea was supported by the fact that moxonidine (which the authors showed to be a partial agonist in in vitro studies) has no hypotensive effects in $\alpha_{2 \mathrm{~A}}$-ARnull mice but lowers blood pressure without sedation in wildtype mice.

So, the authors say that weak partial agonists could be used to achieve $\alpha_{2 \mathrm{~A}}$-AR pharmacotherapy when the sedation effects are not wanted; for example, in the treatment of depression or attention-deficit hyperactivity disorder. And given that members of several receptor families - including G-protein-coupled receptors and nuclear hormone receptors - also show fractional activation properties, this method could also be used in mouse models that are heterozygous for other receptors to identify response-specific agents for various disease states.

6) References and links

Simon Frantz

ORIGinAL RESEARCH PAPER Tan, C. M., Wilson, M. H. MacMillan, L. B., Kobilka, B. K. \& Limbird, L. E. Heterozygous $\alpha_{2 A}$-adrenergic receptor null mice unveil unique therapeutic benefits of partial agonists. Proc. Natl Acad. Sci. USA 99, 12471-12476 (2002) FURTHER READING

Kenakin, T. Efficacy at G-protein-coupled receptors. Nature Rev. Drug Discov. 1, Kenakin, T. Efficacy 